\title{
Study on Tourism Cooperation between Zhuhai Island and Macao in the Times of Greater Bay Area of Guangdong, Hong Kong and Macao*
}

\author{
Xinglong Kan \\ College of Tourism \\ Zhuhai College of Jilin University \\ Zhuhai, China
}

\author{
Hui $\mathrm{Li}^{*} *$ \\ College of Tourism \\ Zhuhai College of Jilin University \\ Zhuhai, China \\ **Corresponding Author
}

\begin{abstract}
In the context of national proposal of the construction of the Greater Bay Area of Guangdong, Hong Kong and Macao, tourism cooperation between Zhuhai and Macao will be further highly integrated. The development of Zhuhai Island, water tourism projects would have new historical opportunity. According to planning, Wanshan Island will build "world-class marine tourism resort". The Central Committee of the Communist Party of China defines the water area of Macao. And it provides a new space for the development of Macao. Also, it provides a new platform for the development of Macao's marine tourism. Zhuhai island tourism and Macao tourism have a good trend of development. This study discusses the cooperation between Zhuhai island tourism and Macao tourism from the aspects of economic development of Wan Shan, Zhuhai island development and the development of Macao marine tourism.
\end{abstract}

Keywords-Zhuhai; island; Macao; cooperation

\section{INTRODUCTION}

In the context of the development of Greater Bay Area of Guangdong, Hong Kong and Macao, tourism cooperation between Zhuhai and Macao will be highly integrated. Zhuhai and Macao are separated by water. And the culture is interlinked. The blood is connected. The geographical proximity between the two places makes the cooperation be more and closer. The tourism departments of the two places have formed a good cooperation and exchange mechanism. At present, Zhuhai takes the whole-area tourism as its focus. And it defines the development goal of "building international coastal leisure tourism destination" with Hong Kong and Macao. It would improve the development of tourism industry and market competitiveness. It also should cultivate the new form of "tourism +" [1].

With integrating the Greater Bay Area of Guangdong, Hong Kong and Macao into the national strategy, the development of Zhuhai Island and aquatic tourism projects have new historical opportunity. According to the plan, Wanshan Island will build "world-class marine tourism

*This research is supported by the project "Innovative Research of Island Tourism Development Model under the New Normal State" of Zhuhai College of Jilin University. Project No.: 2016XJCQSQ026. resort". With the construction of urban agglomeration of Greater Bay Area of Guangdong, Hong Kong and Macao, it would gradually integrate the regions. Zhuhai will face more than 60 million population of the Greater Bay Area in the future. And they would have enough capital and tourists to support the development of Zhuhai Island.

The Central Committee of the Communist Party of China defines the water area of Macao. And it provides a new space for the development of Macao. Also, it provides a new platform for the development of Macao's marine tourism. The expansion of Macao's sea area is conducive to the overall economic and social development. Also, it is conducive to the moderately diversified economic development of Macao. Macao should vigorously promote marine tourism. First, it should have the overall layout and planning. And it could implement the measures step by step in line with the development. It must clarify the water right of Macao, which involves the development. And it should make good use of the water brought about by the development. A lot of infrastructure is needed. For example, it needs to construct the corresponding docks and ports. Secondly, Macao should make efforts to be a world tourism and leisure center. Macao may consider combining water area with tourism, which has a large space for the development.

On the whole, the tourism of Wanshan Islands and Macao has good trend of development under the view of Greater Bay Area of Guangdong, Hong Kong and Macao. The development of tourism of Wanshan Islands and Macao will be discussed from the aspects of economic development of Wanshan District, the development of Zhuhai Island and tourism development of Macao.

\section{TOURISM DEVELOPMENT OF ZHUHAI ISLAND}

\section{A. The Tourism Resources in Zhuhai Island}

Zhuhai is the city with the largest sea area and island area in the Pearl River Delta, the largest number of islands and the longest coastline. The sea area is 6019 square kilometers. The coastline is $691 \mathrm{~km}$ long. There are 146 islands (total 
area of 236.9 square kilometers). It is known as "HundredIsland City". Wanshan Archipelago in Zhuhai city - this island, which is rarely visited until now, has a unique tourism resource. The main tourism development islands are Wailingding Island, Dong'ao Island, Guishan Island, Wanshan Island and so on.

\section{B. Development of Tourism Products of Zhuhai Island}

Zhuhai Island's existing tourism products mainly include leisure tourism products, special tourism products and festivals and tourism products. The island leisure and tourism products mainly include holiday accommodation products such as Gree Hotel in Dong'ao and Jingyun Mountain Resort. It mainly develops the island's tourism products around the island's unique island tourism resources, increases the theme landscape and improves the tourism route and other infrastructure. The island festival tourism product mainly includes three kinds. First, it is based on the folk custom and belief, such as the celebration of the birthday of Matsu, the celebration of the birthday of Zhenwu Emperor, and so on. The second is based on the natural scenery, including seafood and gourmet festival and so on. The third is based on sports events, such as fishing competition, rock climbing competition and so on.

The development of Zhuhai island tourism has achieved remarkable results. On July 8, 2017, the two islands of Dong'ao Island and Wailingding Island of Wanshan Marine Development Experimental Area were officially listed as "National 4A Class Tourism Scenic Spots". "Dong'ao Island and Wailingding Island have successfully established national 4A class tourist attractions, which are important representatives of the development of tourism in Zhuhai. And it is also a new starting point for the development of high-end tourism in Wanshan. In the future, Wanshan will focus on the goal of building a world-class marine tourism resort, adhere to the concept of green development and highend development orientation, jointly create "world-class leisure tourism destination with Hong Kong and Macao, and walk the new way of the development of global tourism." For the island tourism of Wanshan District, it adheres to the concept of "bay area, secret territory of Wanshan". And then, it should shape the unique sculpture of each island. It could give them distinct characteristics from "characteristic, culture, food" and other aspects, such as "Guishan Island-Sailing Town", "Dong'ao Island-Honeymoon Town", "Wailingding Island-Entertainment Town", "Da Wanshan Island-Fishing Town" [2].

\section{OVERALl Plan FOR THE DEVELOPMENT OF TOURISM AND MARITIME TOURISM IN MACAO}

\section{A. Overall Plan for the Development of Tourism in Macao}

The Government Tourism Bureau of the Macao Special Administrative Region has spent two years to do the research and preparation of "overall plan for the development of Tourism in Macao". And it announced the final plan on September 28, 2017. It has formulated the blueprint and plan of action for the development of Macao's tourism industry in the next 15 years. And it would ensure that the tourism industry of Macao can fully cooperate with the development of the state and the SAR government [3].

The initiative of "the Belt and Road" and the Macao Special Administrative Region Government's vision of building a "World Tourism and Leisure Center" have opened up a new opportunity for the development of Macao's tourism industry. The blueprint for the development of Macao's tourism industry in the next 15 years is in line with the goal of building a "World Tourism and Leisure Center". The measures that could be taken to develop collaboration among tourism participants are as follows:

On regional cooperation, Macao has signed a number of tourism cooperation agreements or memorandums with different cities in mainland China, such as the Pan-Pearl River Delta, Hong Kong and Macao, and Guangdong, Hong Kong and Macao. And then, it would promote the development of mutual assistance and reciprocal cooperation [4].

Different national policies have also brought opportunities to expand its regional development for Macao. It would link up the countries and regions of the Eurasian continent through infrastructure investment, enabling Macao to link up with more tourism markets. It would promote tourism development with domestic and foreign partners. "The development of Greater Bay Area of Guangdong, Hong Kong and Macao" will promote the deep co-operation between Macao and its neighboring cities. It would be helpful to the development of "multi-stop" tourism [5].

\section{B. The Plan for the Development of Marine Tourism of Macao}

In order to support the sustained and stable economic and social development of the Macao Special Administrative Region, the sea area of the Macao Special Administrative Region is defined as 85 square kilometers, which has positive impact on promoting the economic and social development of Macao. It has brought new opportunities and opened up new space for Macao's development. It has also injected new impetus into the active construction of "one center, one platform" (a world tourism and leisure center, a business and trade cooperation service platform between China and Portuguese-speaking countries) in Macao. Good management, good use and good development of the water area in Macao is an important part of the construction of China's maritime power.

The Central Committee of the Communist Party of China (CPC) has granted Macao the right of water area. And the development of marine tourism should have many potential business opportunities. There is limited land and sea space around Macao. It is necessary to make full use of this water area and develop the marine economy and marine tourism. Thus, it should make more plans and make better use of policies. The Guangdong and Macao regions are preparing to implement the "Free Yacht Travel". However, the implementation of the program between Macao and other cities of Guangdong Province is still facing problems such as entry and exit, border control and customs clearance. As one of the highlights of deepening the regional cooperation 
between Guangdong and Macao, "Independent Yacht Travel between Guangdong and Macao" made substantial progress in November 2016 after a long period of preparatory work. And it successfully navigated the first free "Yacht Journey".

It must clarify the water right of Macao, which involves the development. And it should make good use of the water brought about by the development. A lot of infrastructure is needed. For example, it needs to construct the corresponding docks and ports. Secondly, Macao should make efforts to be a world tourism and leisure center. Macao may consider combining water area with tourism, which has a large space for the development. Macao is now promoting yacht independent travel. The author believes that it is a short-term visible development advantage. However, it should coordinate with the corresponding policies and measures. And it can refer to some successful regions and countries. To have the development of yacht industry needs what kind of supporting. For example, the finance and port construction needs what kind of support.

The development of yacht independent travel will undoubtedly provide Macao with more diversified source of tourists. However, the policies must be on the place. And the business sector can participate in the operation of the yachting industry. Then, it would be sufficient to support the development of the industry. Apart from having a perfect and safe yacht mooring place, there should also have a place for yacht maintenance and repair. In the future, this will drive the development of the yacht industry chain as a whole. At present, people from all over the world want to prolong the time for tourists to stay in Macao. Independent yacht travel is a good way to attract tourists. In the future, it hopes to develop independent yacht travel. And it will be able to attract more people from the yacht industry to Macao. They could participate in cooperation with their own development. Under the premise of regional cooperation, Macao will have more and more open prospects for the development.

\section{THE TREND OF DEVELOPMENT AND COOPERATION OF MARINE TOURISM BETWEEN ZHUHAI AND MACAO}

\section{A. Development and Cooperation of Marine Tourism Would Accelerate the Construction of Tourism Infrastructure}

To promote the development and construction of the island area, and tourism cooperation with Macao need to further improve the island infrastructure. Wanshan District needs to speed up the construction of Dong'ao Island Ferry Terminal, Wanshan Bay Ferry Terminal and the 13th Gulf Breakwater on Guishan Island. In order to further dissolve the ecological impact of island tourism on the ecological environment of the island, it is necessary to complete the sewage harmless treatment projects of Dong'ao Island and Great Wanshan Island as soon as possible.

At the same time, Macao needs to speed up the location, planning and construction of basic facilities along the coast, such as yacht wharves and passenger transport wharves. And the cost of tourists going to the islands would pave the way for future linkage between Macao and the islands of Wanshan Archipelago [6].

\section{B. Development and Cooperation of Marine Tourism Expands Tourism Space of the Two Places}

The tourism cooperation between Wanshan District and Macao can strengthen the linkage between land and island and expand the tourism space of the two places. The development of Wanshan tourism has entered the stage of leisure holiday. And the opportunities for interaction with Macao will increase in the future. Tourists need more convenient and diversified tourism experience when they are on vacation in the island. With the construction and facilitation of sea passages on Wanshan Island and Macao, tourists will experience the multi-station tourism product.

Macao can follow the direction of the development of the world tourism and leisure center to expand marine tourism. From the perspective of land area, with the development of tourism, Macao's population is indeed constrained by limited space. However, if we shift our horizons to the sea, Macao's space will expand, and we can take advantage of the opportunity to develop the sea. The defined sea area provides broad environment for the development of leisure facilities and recreational activities in Macao. In order to promote maritime tourism activities and allow visitors to enjoy the coastal scenery on the transported waterborne vehicles, it is necessary to develop marine tourism products in the future. This will be helpful to establish the image of Macao. The coastal environment can become the major tourist attraction in the future. Coupled with maritime tourism, it would further develop and promote international water festival events.

\section{Development and Cooperation of Marine Tourism would Enrich Tourist Routes and Tourists Sharing}

The cooperation between Macao and Wanshan will further consolidate the development of Zhuhai's "one-way multi-station" tourism products, bring more diversified domestic and abroad tourists to the two places, and enhance the international influence of the Zhuhai-Macao tourism circle. At the same time, the establishment and development of Greater Bay Area of Guangdong, Hong Kong and Macao is an important opportunity for the development of Macao's tourism industry.

Taking Wanshan Island as the node, it should introduce a new path, organize the characteristic ocean tour line, and increase the diversity of inshore tourism. And inshore tourism is a good link between coastal tourism and island tourism. The island tourism is a good node. Offshore tourism in Macao should establish a good route linking land and Wanshan islands, integrate leisure fishing, coastal activities, special islands and off-shore activities into one. It should actively develop new theme lines of offshore tourism to enrich the diversity of offshore tourism [7]. 


\section{Development and Cooperation of Ocean Tourism Promotes Institutional Innovation}

Macao and Wanshan Ocean cooperation system should promote the implementation of the policy for yachts independent travel in Zhuhai and Macao as soon as possible. Macao has already taken measures to promote yacht tourism. The key to the further development of yacht tourism is to promote regional cooperation and to formulate relevant policies on the specific details of navigation safety, maritime conditions, maritime infrastructure (including berths, immigration and customs inspections, etc.) and travel information [8].

Accelerating the development of cruise ships and docks and simplifying customs clearance procedures are important steps in their development. Wanshan Islands are close to Hong Kong and Macao. The residents of Hong Kong and Macao have to face restrictions in their travel. They must be farsighted. First, they must take more than an hour's boat to Jiuzhou Port to cross the border. Then, they can transfer to the boat. They would enter Wanzhou Island. In addition, the Hong Kong and Macao ships are restricted by the policy of "not berthing the ship and not being the island". And it cannot directly stop at Wanshan Island to receive supplies. It could simplify customs clearance procedures for Hong Kong and Macao residents and foreign nationals. It can first take the Guishan Island and Dong'ao Island where tourism resources and port resources are relatively mature as the experimental unit. Hong Kong and Macao residents can go directly to the islands with their identification documents. The foreigners with Hong Kong and Macao visas can go to the island without checking the visa. Just as Hengqin New Area, it has implemented the policy of "first-tier release, second-tier livelihood". Hong Kong and Macao ships and international cruise ships should be allowed to receive the supply on the islands. And it should actively promote the construction of the first batch of Guangdong and Hong Kong and Macao yachts in Guishan Island. International seafarers who are allowed to wait in international anchorage would resettle and consume on the island. It is allowed to provide replenishment service for docking ships. It allows Hong Kong and Macao yachtsmen and international cruise passengers to travel on the island.

\section{CONCLUSION}

The tourism development of Wanshan Islands has entered the fast lane. And Macao has developed sea areas for marine tourism. The timing of cooperation in marine tourism between the two places is already mature. At the same time, there are still certain obstacles in the future cooperation between Wanshan Island Tourism and Macao Tourism. There is still a large gap between the economic developments of the two places. There is a large gap in the basic composition of the tourism industry. The approach between the two places is still relatively simple. And the process is relatively complicated. The construction of marine transportation infrastructure is imperfect. In order to solve these obstacles and overcome them, first of all, it is necessary to do hardware construction, strongly recommend the construction of related facilities and equipment, and promptly promote the use of a variety of customs clearance ports. In terms of software, it is necessary to refine and implement related policies, conduct more exchanges between the governments of the two places, continuously improve the mechanisms during the exchange process, promote efficient collaborative development between Zhuhai and Macao, and promote in-depth cooperation between Wanshan and Macao's marine tourism.

\section{REFERENCES}

[1] Chen Churong, Guo Yang. Zhuhai Island tourism should be opened [N]. China Ocean News, 2000-06-27 (002). 陈楚荣，郭杨.珠海海岛 旅游应开方便之门[N]. 中国海洋报,2000-06-27(002).

[2] He Yun, Yang Muzhuang. An analysis of island tourism developmen model based on spatial structure - A case study of Wanshan District in Zhuhai [J]. Marine Economy, 2017, 7(04):36-43. 何韵,杨木壮. 基 于空间结构的海岛旅游开发模式分析——以珠海万山区为例 [J]. 海洋经济,2017,7(04):36-43.

[3] Macao Tourism Administration. Formulating the developmen blueprint "overall plan for Macao tourism development" for the tourism industry in Macao for the next 15 years [EB/OL]. http://www.gcs.gov.mo/showCNNews.php?DataUcn= 117230\&PageLang=C,2017-09-28/2018-02-27. 澳门旅游局.制定澳 门旅游业未来 15 年发展蓝图《澳门旅游业发展总体规划》公布 $[\mathrm{EB} / \mathrm{OL}]$.

http://www.gcs.gov.mo/showCNNews.php?DataUcn=117230\&PageL ang $=\mathrm{C}, 2017-09-28 / 2018-02-27$

[4] Gao Jie, Sun Xiaolong. Study on the fluctuation mode and driving mechanism of inbound tourism in Macao [J]. Journal of Northwest Normal University (Natural Science), 2018, 54(01): 119-126. 郜捷,孙 小龙. 澳门入境旅游流波动模式及驱动机制研究 $[\mathrm{J}]$.西北师范大学 学报(自然科学版),2018,54(01):119-126.

[5] Li Zhenhuan, Wang Yaling. Regression analysis of the influencing factors of mainland Chinese residents traveling to Macao $[\mathrm{J}]$. Tourism Research, 2017, 9(03):42-50. 李振环,王亚玲.中国内地居民赴澳门 旅游影响因素的相关回归分析 [J].旅游研究,2017,9(03):42-50

[6] Mou Yanqiu. Scholars call on Macao to seize the opportunity to develop the yacht industry [EB/OL] http://www.xinhuanet.com/gangao/2016-01/06/c_128599741.htm, 2016-01-06/2018-02 -27. 牟彦秋.学者吁澳门把握机遇发展游艇产 业 [EB/OL].http://www.xinhuanet.com/gangao/201601/06/c_128599741.htm,2016-01-06/2018-02-27.

[7] Yang Daokuang. Discussion on the related issues of the construction of tourism and leisure centers in Macao [J]. Hong Kong and Macau Studies, 2016(01):44-51, 94-95. 杨道匡. 澳门建设旅游休闲中心相 关问题探讨 [J].港澳研究,2016(01):44-51+94-95.

[8] Li Yan. Analysis of the integration economic of tourism in Macao and Zhuhai [J]. Market Modernization, 2016(01):148-151. 李颜.珠海 澳门旅游一体化的经济学分析[J]. 商场现代化,2016(01):148-151. 